\title{
THE IMPORTANCE OF EFFICIENCY OF THE SUPPLY PROCESS FOR RETAIL COMPANIES: CASE STUDY
}

\author{
DOI: 10.17261/Pressacademia.2021.1527 \\ JMML-V.8-ISS.4-2021(1)-p.197-202
}

\section{Lucian Gabriel Maxim}

Transilvania University of Brasov, Finance Department, Brasov, Romania. lucian.maximbv@gmail.com, ORCID: 0000-0002-1113-9572

\begin{tabular}{l}
\hline Date Received: October 15, $2021 \quad$ Date Accepted: December 12, 2021 \\
\hline To cite this document \\
Maxim, L. G., (2021). The importance of efficiency of the supply process for retail companies: case study. Journal of Management, Marketing \\
and Logistics (JMML), 8(4), 197-202. \\
Permanent link to this document: $h$ http://doi.org/10.17261/Pressacademia.2021.1527 \\
Copyright: Published by PressAcademia and limited licensed re-use rights only.
\end{tabular}

\section{ABSTRACT}

Purpose- On a retail market dominated by the emergence of large international store chains, there is an increasing emphasis on streamlining processes within companies that have $100 \%$ Romanian capital. In this context, the main purpose of the research is to determine the importance of streamlining the supply process of the company that is the subject of the case study. In order to achieve the goal, the research tries to answer the following question: Does the efficiency of the supply process lead to an additional stability for retail companies? The importance of the research is given by the fact that the retail sector is the main component of GDP in Romania, in 2020 it has or gross growth of $2.2 \%$ compared to 2019.

Methodology- The research is represented by an analysis of the entire activity of a retail company in Romania, using the SWOT analysis model and empirical research.

Findings- Following the SWOT analysis and the empirical research, it was certified that a correct diagnosis but also the systematic improvement of the supply process inevitably leads to a favorable dynamic for the company that is the object of the case study.

Conclusion- based on the findings of the analysis, it can be concluded that changes in organizations are important and according to Kotter's model for a change to last it must become part of the organizational structure and be expressed in daily activities

Keywords: Logistic, performance, retail market, profit, supply process

JEL Codes: L11, L21, L22, L81

\section{INTRODUCTION}

Supply, by definition, refers to the activities of purchasing raw materials, materials, components or finished products necessary to achieve the objectives. It also refers to the relations that are established between the company and its suppliers, in the supply-delivery chain and involves, in addition to the purchasing activity, transport activities, inventory management, storage or handling.

Procurement means that the goods or services necessary for the operation of an entity are made available at the best quality, the lowest costs but also in the best conditions of safety.

The procurement process must be carried out in such a way as to serve the company's interest in satisfying customer requirements to the highest degree of professionalism from this point of view.

The component activities of the procurement process are:

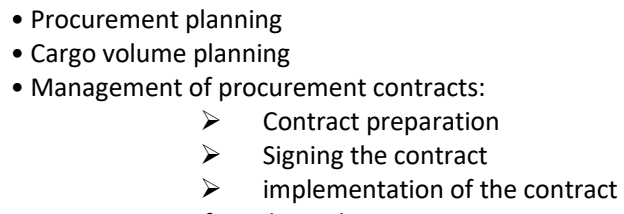

- Management of goods stocks 


\section{LITERATURE REVIEW}

In their paper, Randall et al. (2011), unlike their previous work, found that retailers are more interested in maintaining a balance between costs and services and are increasingly interested in supply chain management, considering it a critical point.

Madhani (2021), in his study on the importance of the supply chain in relation to customers, concluded that those retailers who focus on customer satisfaction with the benefits of the supply chain, manage to increase their performance and gain competitive advantages and their profits will grow. To determine the logistical advantages obtained by traders, studies have been conducted that demonstrate that over time real advantages can be obtained (Richey et al., 2012). At the same time, Stank et al. (2003) talk about the advantages obtained by companies in the retail industry if they approach a high value supply policy to their customers, their satisfaction being a result of the quality of the products offered, the speed of response to customers' wishes or low prices (Kim, 2006).

Good supply chain practices and competitive strategies determine the performance of companies, a fact concluded by Huo et al. (2014) in the research which included a number of 604 Chinese companies in the manufacturing industry. The same result was reached by Mazzawi \& Alawamleh (2013) in their study of a company in the Jordanian food industry. They pointed out that a diversification of distribution methods to customers is closely related to increasing profitability. Uncertainty in product demand can cause supply chain disruption, which is why efficient supply chain management must be able to handle such situations (Christopher \& Towill, 2000). The same is found by Lee (2002) in his paper in which he develops a model to help managers choose the right supply chain strategy taking into account this uncertainty of demand.

What is specific to the retail industry is that retailers have many partners in the supply chain with, in some cases, even thousands of brands that they sell (Agrawal \& Smith, 2009).

Procurement practices, considered environmentally friendly, strongly influence the performance of the entire supply chain and implicitly the profitability of companies (GACHAU \& (Ph.D), 2018).

Of course, implemented technology such as RFID, increases cost efficiency in the supply chain which leads to an increased presence on the sales shelf (Azevedo \& Carvalho, 2012), as well as forcing a more efficient exchange of information in faster product recognition. at cash registers (Azevedo \& Ferreira, 2009).

\section{GENERAL PRESENTATION}

Supermarket is the economic operator of the largest store network in Covasna County.

The company has $100 \%$ Romanian private capital, being a family business, currently among the few companies, belonging to the field of retail trade, in Romania within the local chain of stores (LKA), which managed to develop in the conditions in which this market has been invaded in the last 7-8 years by companies with foreign private capital.

Supermarket has gained a reputation, at least locally, for its seriousness and continuous focus on meeting customer needs.

The company's mission derives from the desire to bring the concept of supermarket and modern trade close to as many communities in the county in which it operates, the market offered by Prahova County being quite large, nationally being the second county in terms of population .

Thus, from its establishment in 2009, which coincided with the first store opened, until 2020, the company managed to open another 19 stores making the store network an important player on the local market and, according to the number of operating points operated, one of the largest traditional networks at national level, the company's strategy aimed at horizontal development.

Also, with the new store openings, the number of employees in the store network increased to 360 employees.

The development of the company has accelerated in recent years, the company managing to tick the opening of 12 new offices, which means about a new opening every 5 months. This development has as main source the change of the management team, about 4 years ago, which resulted in a change in the perspective of the company's activity in terms of development and how it relates to current economic factors.

The company does not have any source of external financing, such as an investor, investment fund or bank loans, the budgets for the development of the store network being fully supported by the revenues generated by the company's activity.

In terms of competition, the company is facing problems, as the number of operators holding foreign capital, ie the large international chains of stores (supermarkets and hypermarkets) has grown rapidly in recent years.

These international chains, which benefit from extremely large development budgets, make the development of the traditional ones in this field quite difficult or even impossible, in some cases, which unfortunately are more and more frequent, even lead to the closure of the points of companies with Romanian capital that cannot keep up with the level of investments supported by these foreign companies.

The main advantages of these companies are offered by the development and promotion budgets, which offer them the possibility to build new locations in the absence of spaces for rent and promotion at national level on the main television stations. 


\section{THE SWOT ANALYSIS}

\subsection{Internal Environmental Analysis}

\section{Strong points}

- Strategy based on the expansion of the store network in localities within the county;

- Issuing the magazine with bi-monthly promotions, continuous listing of new articles in stores;

- Construction of a central warehouse for obtaining lower purchase prices;

- Qualified staff in the field of trade, the salary level of the staff employed above the market average;

- Efficient decision-making structure, important decisions regarding the company being taken quickly; Weaknesses

- The non-existence in stores of freshly cooked food districts which implies a remodeling of stores and special authorizations, a chapter in which international networks excel;

- The supply process of the work points is not standardized, there is no systematic evaluation of suppliers, purchase prices, quality reception;

- $\quad$ Stores are not attractive to customers, they look old-fashioned;

- Machinery and machines with over-wear, with an impact on utility consumption and costs;

- Lack of more efficient software to streamline the processes of purchasing goods, labeling and sales;

- Lack of a Business Intelligence (BI) platform with which the management team can track the performance indicators of stores and cost centers;

- Deficiencies in human resource management, in terms of job definition, staff training, performance appraisal, which explains low productivity.

- Insufficient funds for development and marketing;

- There are no systems that allow a systematic approach to food quality and safety;

\subsection{External Environmental Analysis}

\section{Opportunities}

- Due to the rather large market offered by the county in which the company operates, new localities can be identified that do not benefit from the presence of a player in this field of modern trade.

- Possibility to attract funds by participating in national and European funding projects and programs.

- Existence of specialists / specialized management consulting structures, development and innovation projects, quality management, etc.

- The development continues at an alert pace of the existing competitors on the Romanian market, which leads to a reduction in the number of customers of Supermarket.

- Being a constantly developing market, there is interest from other international networks, which are not currently present on the Romanian market, to enter this market.

- The risk that large store chains will offer a price above the market average for renting locations that perform and are currently rented by the company.

- Legislation in this area is very permissive for large international networks, with measures to encourage and support traditional traders being greatly delayed due to the unstable political environment.

\section{PROCESS ANALYSIS}

The evolution of the company was a very interesting one, in the sense that from 2009 until 2013, it was possible to open only 3 stores. In 2013 , against the background of a visible stagnation of the network development, the general manager of the company who identifies with the administrator of the economic agent, which operates the store network, decides to call on a consultant to transform the three stores into a store network, in the true sense of the word, until that date the three stores each acting independently, the only common points being the accounting and the names of the stores.

It was desired from the employed consultant that he act on all levels and at all levels of the company so that the company overcomes this impasse, he will take over the direct communication between employees and administrator but also the relationship between business partners and administrator, until then, within the company, as there is no such person.

Thus, the analysis, evaluation, improvement and systematization of the processes as well as the centralization of some of them were aimed at:

\section{Basic processes and support}

- Supply point of work;

- Supply of sales space;

- Sale;

- Customer service;

- Identifying customer requirements;
- Implementation planning;

- Satisfaction monitoring;

- Monitoring of internal activities;

- Corrective and preventive actions;

Resource assurance processes

- Providing human resources; 


\author{
- Infrastructure; \\ - Financial management; \\ Control and support processes \\ - Goods control; \\ - Document control; \\ - Record control; \\ - Internal communication; \\ - Process management;
}

\author{
- Development of budgets; \\ - Stock management. \\ Management processes \\ - Strategies and policies; \\ - Performance analysis; \\ - Improving quality; \\ - Establishing responsibilities;
}

As we have shown above, the three stores were independent stores, so there were quite large differences between supply processes, financial management, infrastructure, inventory management or document control, while there are processes for which almost no attention is paid not at all such as identifying customer requirements or monitoring internal activity.

\section{EFFICIENCY OF THE PROCUREMENT PROCESS}

The objectives of the supply process;
- Forecast
- Programming
- Contracting
- Purchases
- Storage
- Resale-recovery

Forecasting and scheduling activities represent the start of the entire supply process. For the forecast, in the first phase, it was decided that all orders would be issued automatically from the store software taking into account the average daily sales and stock in the store at the time of the order which resulted in filling the shelves with unsaleable items.

Also, the store managers had to follow the out-of-stock report daily, in order to identify the rolling stock that they no longer had in stores and for which they had to issue orders to suppliers, but also the daily closing of the management report for validation in the system of the recorded data.

For scheduling and contracting, a meeting was arranged with each supplier in which the terms of the purchase contracts were to be renegotiated, by establishing common purchase price lists and complying with them, thus facilitating the work of store managers who no longer had to return the goods due to discrepancy in purchase prices.

Also during the meetings with the suppliers, the delivery hours to the stores were established, thus being forced to deliver in a certain schedule, thus eliminating the situations in which the suppliers delivered goods very late, especially in the case of perishable products of daily necessity.

For the purchasing activity, it was wanted that the representatives of the stores carry out very rigorously the quantitative and qualitative reception of the goods, thus validating the invoice that was to be paid. In support of this reception activity, it was decided that video cameras should be installed at each unloading ramp for better control or detection of errors that may occur in the process of receiving the goods, especially for quantitative reception. At one of the stores, a space used for storing stationery was identified, which was not used at full capacity, so it was decided to set up a central office in that space where the management software supervisor had moved, which ensures the complete management of the product nomenclature and in which, the procedure of grouping the articles by product groups was started in order to better analyze the non-performing product groups, but also those that performed.

Payments were centralized to be made from the newly established office, which relieved the store managers of an additional and very cumbersome task, because they made payments manually, but not from software, so the record of unpaid invoices was made on a notebook and additional documents had to be made to reduce the time they should have spent on other store management activities.

Warehousing is a very important activity of the whole process due to the fact that the stocks of goods represent a current asset in the form of goods, this being the only difference compared to the cash of the company. That is why the daily follow-up of reports such as over-stock that highlights the products without the desired turnover thus leading to fixed assets, implicitly money.

A space was identified next to one of the company's stores where it was possible to arrange a warehouse, not very large, but which allowed the centralized purchase of larger quantities of products under promotion, so that the profit margin for those products to increase, which agreed to suppliers who were thus able to meet their monthly targets and thus reduce their delivery cost.

In the warehouses, the storage spaces were rebuilt to ensure the optimal conditions in which the goods are stored and the shops that were deficiencies in this respect were additionally equipped with shelves or cold spaces.

Following the centralization of purchase and sales prices, store managers lost their freedom to change the prices of local products, thus eliminating the possibility for suppliers to grant promotional purchase prices depending on the quantity ordered. 
The procedure for communicating promotional prices for the products to be promoted in the joint magazine of the stores was also established, which was new and relieved the store managers of this process of reducing prices on each store.

With this centralization, the purchase prices became unique, the supplier being obliged to announce at the headquarters any change in the purchase price as well as periodic promotions, in order to be implemented in stores and marked on the appropriate shelf with different color labels.

The store managers were responsible for any non-compliance by the supplier with the purchase price to put the unsuitable goods separately, contact the supplier, make a return, and then wait for the minus invoice to be issued for those products.

It was established that the items that did not perform in the warehouses should be delisted from the nomenclature and returned to the suppliers to recover the investment made or resell these stocks at promotional prices, the price difference will be borne by both the supplier and the store, especially for products whose packaging has been degraded or products which are about to expire.

\section{CONCLUSIONS}

According to Kotter's model, for a change to last, it must become part of the structure of the organization and express itself in daily activities. Efforts are being made to show that change affects every aspect of group dynamics, so the group becomes convinced of the usefulness of change.

It is important that those who make decisions in the group (whether they are older or newcomers) remain interested in the effects of change, otherwise there is a risk that in time things will return to the state before the implementation of change.

These things are possible if we discuss the progress made in order to streamline processes whenever the opportunity arises. Examples are given from one's own process of change but also from examples from elsewhere. The ideals and values of change must be implemented in the process of receiving new members in the group but also in the process of educating those already engaged in the group.

Was it necessary to change and adapt to the market conditions of the supply process within the organization? Yes.

Today, the company has the largest network of stores in the county, with 20 stores, being present in 17 localities. At the moment, the company is working on standardized procedures in terms of basic and support processes, including the process of supplying the work point, which facilitates the entire sales process.

Is there things for improvement? Yes. Daily.

It is necessary a continuous adaptation to market conditions, when you consider that you have nothing to change then you are like out of the market.

The desire to evolve too fast, the maintenance of old managerial practices for too long, poor communication, superficial approach to the processes of training staff involved in making change, talking without doing anything or hesitation are mistakes that must be avoided in implementing change.

\section{REFERENCES}

Agrawal, N. M., \& Smith, S. A. (Stephen A. (2009). Retail supply chain management : quantitative models and empirical studies, 8, $327-341$.

Azevedo, S. G., \& Carvalho, H. (2012). Contribution of RFID technology to better management of fashion supply chains. International Journal of Retail and Distribution Management, 40(2), 128-156. https://doi.org/10.1108/09590551211201874

Azevedo, S. G., \& Ferreira, J. (2009). RFID Technology in Retailing: An Exploratory Study on Fashion Apparels. The IUP Journal of Managerial Economics, VII(1), 7-22. https://ideas.repec.org/a/icf/icfjme/v07y2009i1p7-22.html

Christopher, M., \& Towill, D. R. (2000). Supply chain migration from lean and functional to agile and customised. Supply Chain Management, 5(4), 206-213. https://doi.org/10.1108/13598540010347334

GACHAU, N. N., \& (Ph.D), D. M. M. (2018). Influence of green procurement practices on supply chain performance in humanitarian organizations in kenya: a case of Kenya red cross society. Strategic Journal of Business \& Change Management, 5(4), 832-857. http://strategicjournals.com/index.php/journal/article/view/927

Huo, B., Qi, Y., Wang, Z., \& Zhao, X. (2014). The impact of supply chain integration on firm performance: The moderating role of competitive strategy. Supply Chain Management, 19(4), 369-384. https://doi.org/10.1108/SCM-03-2013-0096

Kim, S. W. (2006). Effects of supply chain management practices, integration and competition capability on performance. Supply Chain Management, 11(3), 241-248. https://doi.org/10.1108/13598540610662149

Lee, H. L. (2002). Aligning supply chain strategies with product uncertainties. California Management Review, 44(3), $105-119$. https://doi.org/10.2307/41166135

Madhani, P. M. (2021). Retail Supply Chain Management: Building a Customer-Focused Approach with Competitive Priorities. The IUP Journal of Supply Chain Management, 18(2), 7-27. 
https://www.researchgate.net/publication/354780611_Retail_Supply_Chain_Management_Building_a_CustomerFocused_Approach_with_Competitive_Priorities

Mazzawi, R., \& Alawamleh, M. (2013). The impact of supply chain performance drivers and value chain on companies: A case study from the food industry in Jordan. International Journal of Networking and Virtual Organisations, 12(2), 122-132. https://doi.org/10.1504/IJNVO.2013.053744

Randall, W. S., Gibson, B. J., Defee, C. C., \& Williams, B. D. (2011). Retail supply chain management: Key priorities and practices. International Journal of Logistics Management, 22(3), 390-402. https://doi.org/10.1108/09574091111181381

Richey, R. G., Adams, F. G., \& Dalela, V. (2012). Technology and flexibility: Enablers of collaboration and time-based logistics quality. Journal of Business Logistics, 33(1), 34-49. https://doi.org/10.1111/J.0000-0000.2011.01036.X

Stank, T. P., Goldsby, T. J., Vickery, S. K., \& Savitskie, K. (2003). LOGISTICS SERVICE PERFORMANCE: ESTIMATING ITS INFLUENCE ON MARKET SHARE. Journal of Business Logistics, 24(1), 27-55. https://doi.org/10.1002/J.2158-1592.2003.TB00031.X 